\title{
Coaching and mentoring at family businesses in process of transition
}

\section{Abstract}

According to the Spanish saying ('Cuentas claras, amistades largas') the secret of a long friendship is clear accounts. How can this be interpreted in our country's enterprises sector? More specifically in that economic milieu where, based on the EU's expert estimates (Mandl 2008), the ratio of family businesses is $70-75 \%$ whose roots go back to the period of the change of regime for most of them. So in the near future, based on the international experiences, showing both the micro and macroeconomic importance of the processes of succession and generation change, the passing on of leaders and owners' roles are deemed as critical and are thus in the focus.

One of the theoretical debates concerning family businesses centres round a provocative question: namely whether the world would be better if family businesses operating under professional leaders behaved as businesses free from family influence. We reply no to this pseudo naïve question, and at the same time from our point of view as the result of symbiosis of familiness (resources thanks to family participation) and professionalization, the survival of family businesses forming the backbone of the enterprise sector in Hungary may be improved significantly.

In this paper we give an outlook and a literature review about the status of the Hungarian family businesses and we present the relevance and possibilities of succession planning. As the succession is not in quick and easy process, it can be supported by externals as well, like advisors, coaches and mentors; we review that where and what can be the role of these external supports in case of succession issues in family businesses.

Key words: family business, succession, mentoring

\footnotetext{
1 Intézetvezető, egyetemi docens, BGE-PSZK, Számvitel Tanszék; e-mail: szirmai.andrea@uni-bge.hu.

2 Adjunktus, BGE-PSZK, Számvitel Tanszék; e-mail: nemeth.krisztina@uni-bge.hu.

DOI: http://dx.doi.org/10.31570/Prosp_2019 01_4.
} 


\section{The status of family businesses in Hungary}

Yet family businesses form an important segment of business environment all over the world, and as a relevant set of the SME sector at international level, there is no secondary database available to precisely reveal among the Hungarian enterprises the family businesses' role and presence in the sectors, size categories; several studies underline the family businesses' importance in national and local economy (Csákné Filep 2012; Németh 2018; Kása et al. 2017). There is not a generally accepted definition for family businesses in Hungary either; the family businesses can be arbitrarily defined along the characters determined by the researchers and classified this way. The ratio of family businesses in Hungary is around 50-70\% (Kása et al. 2017).

Bálint (2006) has identified two preferred ways for succession - based on his research in Hungarian SME's - on the one hand generational succession, on the other hand the selling of the business for a third part and the following factors have an influence to the choice: incumbent's age, personnel characteristics of the potential successor, features of the industry and rate of the family ownership.

Csákné Filep (2012) analysed possible outputs from a company sample with a staff of 3-100 employees, and identified the following results for each output:

- ownership and management of the company remain within the family (48.5\%)

- the ownership of the company remains within the family, the management performs an external party (15.8\%)

- sale to owner co-owner (6.9\%)

- sale to employees $(0.8 \%)$

- sale to third parties (8.9\%)

- did not think about it (14.6\%)

- closure of a business (4.5\%).

According to Csákné Filep (2012), 18.2\% of the sample had a formal succession plan in the 2008 survey, $49.3 \%$ made only informal succession plans, while $32.5 \%$ did not deal with succession planning process.

Németh K.-Németh Sz. (2017) focused on medium-sized companies in her survey ( $n=192$ ), 39\% of the respondent companies has less than 25 employees, $8 \%$ between 26 and 50 employees, 20\% between 51 and 100 employees, 28\% between 101 and 250 employees, while only $5 \%$ of them has more than 251 employees and apart from the 127 family firms, $35 \%$ went through the family succession. In the next 10 years, $58.3 \%$ 
of respondents are expected to have a generation change and $23 \%$ of respondents currently have family ownership/leadership role transfer. The $83.2 \%$ of family businesses aim at retaining the family business, so the commitment to preserving the long-term attitude towards family businesses and the familiarity of generations across generations seems to prevail. $66.4 \%$ of respondents believe it is important for the business to prepare the next generation for succession, sharing knowledge between the incumbent and the successor, and $71.1 \%$ say that it is important to develop the family's human capital. However, only the $7 \%$ of the respondents have a formal succession plan.

Wieszt and Drótos (2018) analysed the possible ways of succession, and identified the following results: ownership and management of the company remain within the family (71.2\%); management of the company remain within the family and selling the family firm for external party partly or fully (5.2\%); management of the company remain external manager, but the ownership of the company remains within the family (2.6\%); external management and ownership succession (11.1\%); liquidation of the business (9.8\%).

\section{Succession planning at family businesses}

As Martínez, Stöhr and Quiroga (2007) state, if family-controlled businesses make management and direction bodies professional, they guarantee transparency towards non-family minority owners, they can defeat their greatest weakness, opaqueness due to intertwining of family and corporate systems, and they can operate successfully at last. Of course this cannot be imagined radically, so it is more reasonable to do some incremental developments.

Succession is one of the most important processes of a family business's life cycle due to its substantive effect on the firm's strategy, culture, goals, values, structure, staff, and survivability (Ahlers et al. 2014).

The succession-planning process has two main goals:

(1) the selection of the successor, which includes setting criteria or defining a pool of possible candidates (Miller et al. 2003);

(2) the preparation for the transfer of management control as well as ownership shares from an older to a younger generation (Sharma et al. 2003). 
Numerous examples around the world show that succession is also a challenging process that many businesses struggle with (Mussolino-Calabro 2014), in particular with defining the right timing, finding the right successor, and managing the succession process in a fortunate way (Sharma 2004).

The generational succession usually passes off without a formal or informal succession plan. The main reasons for the unplanned succession are the following: disease or death of the founder, retirement of the founder family, burn out and lifestyle change, divorce, fusion etc. If the founder of the family firm does not makes a succession plan and does not make arrangements for the succession or professionalization of the family business, the family firm may be soon in trouble.

\section{Phases of succession planning process}

Towards the answering the unplanned succession, first we take under consideration the four important phases of the effective succession planning process and highlight possible reasons for unplanned succession:

1. the trigger phase,

2. the preparation phase,

3. the selection phase, and

4. the training phase.

\section{The trigger phase}

The first element in succession planning is the ability of the incumbent to hand over the business. The founder of the family business is usually a general desire to hand over the business to their children one day (Chua et al. 1999), but they tend to postpone their decision to retire from business again and again, inheritance candidates stay in a longer waiting position, the so-called 'Prince Charles Syndrome' (Rothwell 2010). he family is a very complicated emotional system, with many members, relationships and affection, conflict opportunities (sibling rivalry, divorce, adopted children and blood children, etc.), which can make it difficult to design a succession.

The advisors are external consultants from family businesses, such as mentors, coaches, lawyers, accountants, and consultants, whose family members have longstanding professional relationships (Nicholson et al. 2010). Reliable counselors can 
improve the effectiveness of the inheritance process by mentoring incumbents and offspring, giving new insights into succession (Salvato-Corbetta 2013).

\section{The preparation phase}

The leading tasks in this phase are the following (Miller-Steier-Le Breton-Miller 2003:

- creating an initial vision of how the business should operate in the future,

- clarifying the goals, rules, and guidelines that every internal stakeholder must follow during the succession process,

- defining the time plan and establishing the milestones.

In family businesses, in which incumbent and successor have already shared a long history, this process is likely less complicated.

The main reasons for the unplanned process in the second phase are the following:

- lack of parallel planning process in the family firm.

The Parallel Planning Process is the traditional model of family business planning. The PPP becomes a tool for integrating and balancing family and business thinking and action. The PPP uses a series of planning and programming activities that lead the family and management to a business strategy that matches the family's interests and the business' potential. Strategic thinking by the family and management teams leads to their mutual commitment to a Shared Future Vision. Based on this shared vision, both systems begin their respective planning activities leading to the development of the Family Enterprise Continuity Plan and Business Strategy Plan (Carlock-Ward 2001).

What can The Family Enterprise Continuity Plan regularize?

- Help the family to explore their level of commitment to the business.

- Identify core family values.

- Agree on a Family Business Philosophy.

- Develop a Family Vision.

- Appreciate the nature and sources of conflict and a model for improving family fairness.

- Understand the importance of family meetings and the development of family agreements. 
- Recognize how life cycle influences careers and management transitions.

- Appreciate the challenges of preparing the next generation of family members for business and family leadership roles.

- Develop systems to support meaningful family career experiences.

- Recognize how life cycle influences ownership transitions.

- Consider the choice of future ownership structures.

- Prepare estate plans that address financial needs, estate taxes and future ownership considerations.

- Develop an effective family and business governance system.

Many times, the president or senior family members are blamed for the lack of planning for any of the above reasons. However, this type of thinking fails to recognize that all family and non-family stakeholders play a role in family business decision-making and action taking. They also create obstacles to planning. (Carlock-Ward 2001).

\section{The selection phase}

The selection phase includes three major tasks such as:

- defining the pool of candidates, criteria for and rules of selection,

- creating the communication plan, which can share news about the succession to stakeholders (such as employees, suppliers, or customers), and

- making guidelines for the successor's future training.

In family firms the selection criteria used by the incumbent are often guided by personal fit as well as family needs and some other criteria: good relationship with the employee, the suppliers and customers, one the other hand the communicating skills and organising skills are the most important (Csákné 2012), and are less driven by profit-maximization as compared to non-family firms (Chua et al. 2003).

The main causes of the unplanned succession are the following in this third phase:

- sudden death or disease of the selected successor or the incumbent,

- unpleasantness among the family members (divorces, sibling conflicts, generational conflicts),

- foreign investor make a bid for the family business, 
- close-down of the family business due to financial crisis or departmental recession,

- opportunity for fusion, and

- emigration of founder family or the potential successor(s).

\section{The training phase}

After a successor has been chosen, the succession process enters the training phase, in which he or she is trained and prepared for his or her new role. Family firms typically take an approach to training that is more personal and relationship-oriented.

Therefore, the quality of the incumbent-successor relationship is important because those commitments have a positive effect on succession planning and successor training (Lansberg-Astrachan 1994).

The main reasons for the unplanned succession can be the following:

- the selected successor by the formal training can find new career opportunities outside the family business,

- the above-mentioned internal (death, disease, divorce) and external reasons.

\section{Succession challenges in Hungary}

Based the latest information of the National Ministry of the Economy at least half a million FB have to confront the process of succession in the near future. There are some current challenges in connection with succession in Hungary (Csákné Filep 2012; Konczosné, 2014; Makó et al. 2017; Heidrich et al. 2016; Németh K.- Németh Sz. 2017; Makó et al. 2016):

(1) Succession and strategic planning; defining an exact timing of the transition The generational succession usually passes off without formal or informal succession plan in Hungary. The main reasons of the succession are the following: disaster of the founder, dead of the founder, flit of the founder family, burn out and lifestyle change, divorce, fusion etc. If the founder family not makes a succession plan and not makes arrangements to the succession or professionalization of the family business, it will be the devil to pay. 
(2) Lack of trusted advisor

The culture of family firms in Hungary is much closed, so the first generation of the small or medium sized family firms manage the firm's succession process without external specialist, coach, mentor or mediator.

(3) Few succession experience in Hungarian SME sector

Most family firms have been founded in the last 25 years and are micro-, small- or medium sized enterprises.

(4) Closed business culture, paternalistic leadership.

(5) Lack of potential family or non-family successor

A nonsignificant proportion of Hungarian university student (3-3.8\%) reported in the GUESSS research (Gubik-Farkas 2017) that they intended to work as successor in family firm after graduation.

(6) Lack of parallel planning process and family government methods in the Hungarian family firms;

(7) Emotional attachment

The family firms founders are characterized by emotional attachment to the firm, so they tend to postpone their decision to withdraw from the business again and again with succession candidates remaining in a prolonged waiting position.

(8) Disharmony among the family members, intergenerational conflicts and sibling rivalry are very important factor in succession process.

(9) In Hungarian SME sector don't have enough information in connection the succession process, the contingencies and the threats of the different variant solutions (tax, fee, judicial outgrowth and accounting tasks); financial aspects of succession.

(10) Lack of credence of the Trust as atypically exit strategy.

A significant fraction of family businesses in Hungary with significant domestic impact are currently facing important questions that the succession of generations raises, strategically, legally, and logistically; or they are struggling with the legal clarification 
of issues raised by succession (the relationship with each other of parties; selection of legal framework; the legal standing/situation of family member and non-family member managers), which have an intense impact on operational challenges, possibilities of growth, strategic decisions and at the same time on staying competitive. Another phenomenon, which is going on in parallel with the one just mentioned, is a kind of professionalization, which results in the growth of the competitiveness of certain family businesses, but which causes others to be left behind in the face of competition. These two effects are not only visible in Hungary: businesses founded just after the regime changes all over Central and Eastern Europe must deal with individual local problems of succession, of becoming professional organizations, and the possible effects of these on firms' competitiveness, growth prospects and performance.

There are some scenarios or alternative ways for the business continuity but these versions have several effects on the family and the business too.

\section{Professionalization level}

Based on the empirical research (Németh K.-Németh Sz. 2017) we can conclude that $60 \%$ of the family businesses $(n=113)$ have strategic and business plans written down, and less than $60 \%$ of the family businesses operate accounting, controlling, internal audit and enterprise resource planning systems. As for formalised training system and corporate social responsibility institutionalisation is of even a lower level. The next segment in the concept of professionalism to be analysed is the application of strategic management instruments (Sági 2017), the type and the number of the instruments applied (Sági-Korom 2005). Family businesses can be characterised by a higher strategic instrument intensity than the non-family ones; while the number of the strategic decision support tools applied by family businesses is 3.15 on average. The application frequency of strategic and operative methods is presented in Table 1 and Table 2.

The most popular strategic tools are strategic planning and competitor analysis, more than the half of the businesses in question use them. Only in case of one third of the businesses appear the SWOT analysis, strategic pricing, customer profitability analysis and value analysis. The other methods show lower application frequency than that in case of the businesses in the sample.

The intensity of operative decision support tool application is only slightly exceeds the extension of the strategic tool application (3.39).

In the course of the research Németh K.-Németh Sz. (2017) analyzed the popularity of the corporate governance tools in Hungary, and visualizing this as the so-called fam- 
ily governance pyramid he divided it into three family corporate governance segments: widely spread informal methods, formalized methods for restricted employees, and as being the quasi legal category solutions relevant in succession planning and management of gap between generations.

Figure 1: Frequencies of the family governance methods

\begin{tabular}{c} 
family constitution $(0.9 \%)$ \\
family foundation $(1.8 \%)$ \\
family protocol $(8.0 \%)$ \\
\hline formal family communication \\
family form $(8.8 \%)$ \\
\hline family council $(13.3 \%)$ \\
formal family meeting $(17.9 \%)$ \\
family office $(19.5 \%)$ \\
\hline informal family meeting $(33.0 \%)$ \\
\hline informal family lunch $(52.7 \%)$ \\
\hline
\end{tabular}

The 27 percent of family businesses interviewed do not apply family corporate governance solution at all. The 31 percent of respondents use 1-2 governance methods, with $24 \%$ already 3-4 family governance solutions integrated into the family business management system, while only $4 \%$ of respondents are considered to be truly professional in terms of the extent of the applied methods of corporate governance.

In the family businesses' life and their growth potentials it is a critical point when the founder recognizes the limits of the leadership based on intuition and traditions, and by applying professional tools and principles he ensures seeing clear in connection with the economic effects of decisions. The founder generation's task and responsibility is to develop the family members' human capital in favour of a long-term orientation.

In the family businesses' growth path in many cases a break is a consequence of that the family management does not recognize in time if professionalism is needed since 
they mean the obstacle in the business' development. If the idea and the need for calling in an external professional manager are born in a family businessman, it can be a beginning of a new growth phase.

Palócz and Vakhal (2018) conclude based on 3350 SME-s case studies - analysed the growth rate and the evaluation of the firms - that 1800 firms eliminated in this period, 600 firms could be medium-sized entrepreneurship. Only 300 medium-sized firms were able to growth between 2000 and 2016.

Based on study and research project $(n=250)$ of Wieszt and Drótos (2018) the researcher concluded, there is a strong relationship between the financial performance (growth) and the level of socio-emotional wealth elements, the external partnerships and the involvement of external experts.

Fenyvesi et al. (2015) based on a research project with survey method analysed the training habits of Hungarian mid- and top-lever managers $(n=682)$. The main results of this project: The proportion of mentoring is smaller than 1 per cent, the majority of leaders 'take their problems home' as 78 per cent of them expect help from family members, and 43 per cent from friends, and still 14.4 per cent of the respondents seek assistance from consulting firms.

\section{Succession with external support: consultant, mentor, coach}

Consulting, coaching and mentoring are all highly effective ways for a company - and in our case, for a family business as well - to unlock the potential of its people and at the same time improve business performance. The business performance can mean the everyday operation of the business or the situation of succession too.

The words of consultant, mentor, coach have become so worn out as to almost have lost all distinction between each other. The problem is, whenever someone creatively attempts to use different words, these coined terms cause even more confusion. The trick is to know when and where each discipline will produce the best results.

\section{Consultant}

Business consulting is based on the expertise of the consultant - in knowledge, skillset and technology. It allows them to import and practise their specialist activity in a company that does not have the resource or knowledge in-house. The management consultant's skill-set is focused on building their own internal resources, in order to apply them for the client company's benefit. A consultant can and will tell you what 
you are doing wrong and how you should change. Sometimes they will even make the change for you. They typically operate in finite, short spurts with clients in an attempt to make specific changes to achieve a direct result. At best, they provide big returns on investment; at worst, they are plumbers that keep sending you the bill but never fix the drain. The most important trait of a skilled consultant is attention to detail. In short, a consultant is a careful analyst who makes specific recommendations for change.

Reviewing the wide range of the provided services of the consultants, a hierarchy can be set of consulting purposes:

\section{Figure 2: Hierarchy of consulting process}

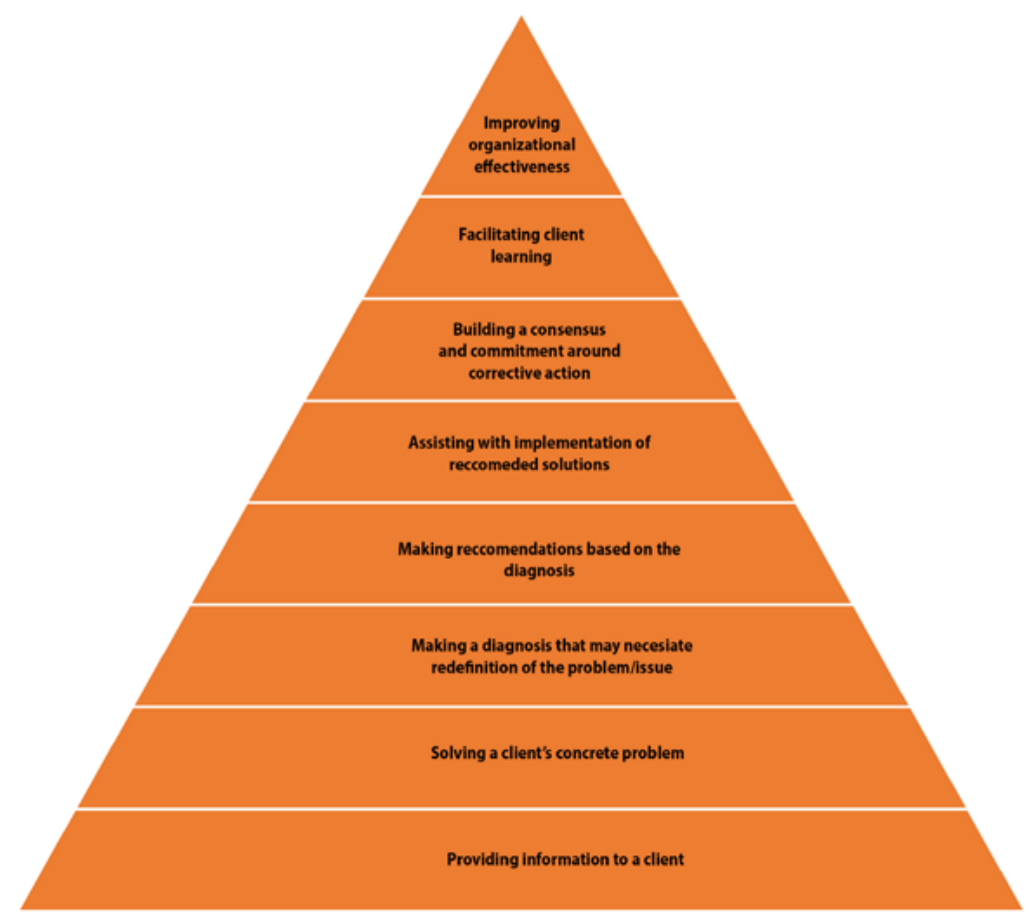

Source: Turner (1982: 2)

\section{Coach}

Coaching assumes that the client has the necessary capability and helps them to discover it for themselves. The coach's skill-set is focused on unlocking the inherent knowledge and awareness in the client and helping them to build on that to act outside their previ- 
ous comfort zones. A coach is an agent of personal behavioural change, and coaches 'teach a man to fish'. The most important trait of a wise coach is to be good listener.

In short, a coach is a trainer guiding individuals (and sometimes groups) through long-term growth. Coaching acts to transform, liberating the innate strengths and talents of the person being coached, overcoming blocks, and unlocking potential that may not yet have been seen. A coach is normally an external professional, who provides unbiased listening, questions, challenge and truth-saying, and acts as a sounding board. The coach's skills unlock the coached individual's mindsets, creating greater selfawareness. The forward-thinking, action-oriented coaching process allows for clearer action planning.

Coaching is a confidential, professional and equal partnership with a reproducible self-discovery process and a premise that the person being coached is highly capable, creative and resourceful. The agenda for the one-to-one sessions is set by the 'coachee', and often focuses on problem-solving for regular organisational and interpersonal issues.

'Coaching is around specific performance issues or goals. Coaches are subject matter experts, such as learning a new computer program. Most coaching is short term; it typically doesn't last over a year. In mentoring relationships, you're usually talking about soft issues, people issues, and cultural issues. How to be a more effective communicator or motivating a high-performing team... A coach is a person you hire to help you with a specific issue or goals. A mentor is a person whom you cultivate a relationship, based on a mutual exchange of information and perspective' Tyler (2004).

According to the literature of coaching, there are several types of coaching serving different purposes (Zentis 2016) and there is a type of coaching especially for succession situations.

\section{Succession coaching}

The succession coach helps assess potential candidates for senior management positions and prepares them for promotion to more senior roles. This type of coaching may be used in any organization that is experiencing growth or turnover in its leadership ranks. It is especially helpful in family businesses to maintain the viability of the firm. Since assessment is often part of this intervention, clear expectations and ground rules for confidentiality are essential. It may be necessary in some companies to use separate consultants for assessment and coaching. 


\section{Mentor - mentoring}

The word 'mentor' comes from Greek myth, in which the legendary king Odysseus went off to fight in the Trojan War, entrusting the care of his son to a friend called Mentor. The origin of the word means 'enduring' and is usually used to describe a sustained relationship between an experienced person and someone who is in the initial stages of their development in the same field. The word has become synonymous with the idea of a trusted adviser. Mentoring is also associated with apprenticeship based on historical practice, when the worker followed a path beginning with apprenticeship to a senior colleague and working up to the final rank of master craftsman. Mentoring nurtures the growth and potential of both participants within their business roles. The purpose of mentoring is to develop the talent of both individuals and enrich the organisation's human capital, thereby benefiting the organisation.

So, there are several other explanations for mentoring and the relationships that are involved in mentoring, but altogether mentoring has become chiefly characterised as a 'parental type' relationship between a more experienced person and a developing individual (Wolverhampton 2009).

Mentoring has different definitions, mainly derived from evidence-based practice not academic studies - and testimonials and opinions of HR practitioners and business consultants (Merriam 1983; Clutterbuck 2014).

Mentoring is a complex, social and psychological activity (Roberts 2000) and therefore attempts at a universal definition of mentoring have become a quagmire (Hagerty 1986). Mentoring is a slippery concept (Daloz 1986) and as such definitions vary with respect to differing dimensions such as hierarchy, intensity, duration and partnership (Gibson 2004) and according to national and cultural traditions.

In the US, mentoring tends to be considered as an interpersonal exchange between a senior person and a junior, where the mentor will guide, teach, share their experience and wisdom (Zey 1984; Whitely et al. 1992; MacLennan 1999; O'Brien 2003). 'A mentor is someone who passes on his or her experience and wisdom by coaching, counselling, guiding or partnering in every possible permutation, from volunteer tutor to angel investor' (O'Brien 2003).

Within the UK and Europe, a more general approach is evident which tends to describe mentoring as help by one person to another, helping others to achieve various personal outcomes, specifically those related to career success (Gibson 2004), with no mention of the power relationship, hierarchy or experience needed (Shea 1992; Parsloe-Wray 2004). 'A process which supports learning and development, and thus 
performance improvements, either for an individual, team or business' (ParsloeWray 2004).

With all these interpretations together, the consensus can be in the definitions that mentoring is a process that supports and encourages learning to happen (Parsloe-Wray 2004) and that mentoring is an intense and powerful one-on-one developmental relationship that leads to skills development (Wanberg et al. 2003). 'Mentoring can be seen as the most intimate of learning approaches. Its primary focus is not the development of technical competence but on the acquisition of the largely intuitive skills that make people capable of operating effectively at higher levels of management or in a different situation' (Clutterbuck-Lane 2004).

An effective enterprise mentoring relationship gives the mentee an opportunity to receive medium-term or long term personal and professional support. The relationship enables the mentee to explore their personal and professional situation in order to develop strategies and goals that will have a positive impact on their business enterprise. The mentor should have the personal experience and skills to give the enterprise owner the right level of support, but it is equally important for the mentoring to be done in the most appropriate way. Mentoring is based on establishing a relationship built on equality, openness and trust and it shall be very supportive.

Guiding the mentee to look for a wide variety of options and alternative actions to solve the problem individually, rather than giving them answers or solutions, for most mentoring relationships, the main objective is for the mentee to gain new personal skills, experiences and knowledge that will lead to new insights, a greater vision, and new attitudes and behaviours to lead to higher performance. The mentor should not tell the mentee what to do, only the mentee can decide what goals or actions to implement.

So the mentoring is:

- A one to one relationship over a period of time between a less experienced person (mentee) and established professional (mentor) which provide support, guidance and practical help.

- A process by which an experienced professional shares their personal skills, knowledge and experience with another person.

- A means of enabling a less experienced person to gain the necessary skills, knowledge and confidence to be able to perform at a higher level.

- An opportunity for a less experienced person to gain access to impartial, nonjudgmental guidance and support. 
- A process of working together to achieve predetermined goals and objectives.

- A two-way process through which both parties derive satisfaction from their progress, and success is attained through working together.

Clutterbuck (2014) set ten competencies crucial for a good mentor:

1. Goal clarity.

2. Conceptual modelling.

3. Business/professional savvy.

4. Relationship management.

5. Interest in developing others.

6. Behavioural awareness/understanding others.

7. Commitment to own learning.

8. Self-awareness.

9. Communication competence.

10. Sense of proportion/good humour.

\section{Coach, mentor, consultant}

Coaching and mentoring seem to be the two most compared and contrasted learning processes. The Coaching and Mentoring Network state that coaching and mentoring are processes that enable both individuals and corporate clients to achieve their full potential' and they argue that the common thread that unites both types of service, are that they offer a vehicle for analysis, reflection, learning and action that ultimately enables the client to achieve success in one or more areas of their life or work.

Mentoring is a role that includes coaching, but also embraces broader counselling and support, such as career counselling (Lansberg- Astrachan 1994). Coaches do not mentor as they are hired to help with performance issues or specific skills and do not get involved in the softer people issues, career management issues, etc. (Tyler 2004; Csizmadia-Csillag 2017.)

The following similarities and differences can be identified between consultant, coach and mentor (Distelberg-Schwarz 2013): 
Table 1: Similarities and differences can be identified between consultant, coach and mentor

\begin{tabular}{|c|c|c|c|}
\hline Activity & Consultant & (Traditional) Coach & Mentor \\
\hline Purpose & $\begin{array}{l}\text { Explore professional } \\
\text { issues and problems }\end{array}$ & $\begin{array}{l}\text { Action } \\
\text { orientated }\end{array}$ & Personal growth \\
\hline Focus & Individual or company & $\begin{array}{l}\text { Task/skill of the } \\
\text { individual }\end{array}$ & $\begin{array}{l}\text { Individual = Mentee } \\
\text { and the family business }\end{array}$ \\
\hline Delivery & Typically 1:1 & Typically 1:1 & Typically 1:1 \\
\hline Ownership & Client & Coachee & Mentee's \\
\hline Goals set by & Client & Job/Organization & Mentee's \\
\hline Key actions & $\begin{array}{l}\text { Provide solutions for } \\
\text { professional problems }\end{array}$ & $\begin{array}{l}\text { Specific job/task } \\
\text { or skills related } \\
\text { discussion-guided } \\
\text { (by job need) }\end{array}$ & $\begin{array}{l}\text { Listen and be guided } \\
\text { by the client - focus } \\
\text { on capability and } \\
\text { potential }\end{array}$ \\
\hline Timescales & Short term sets of sessions & $\begin{array}{l}\text { As needed basis/short } \\
\text { term }\end{array}$ & Long term \\
\hline $\begin{array}{l}\text { Who is } \\
\text { involved? }\end{array}$ & $\begin{array}{l}\text { Consultant }+ \text { Client }+ \\
\text { 3rd party (if necessary) }\end{array}$ & $\begin{array}{l}\text { Coach }+ \text { Coachee }+ \\
\text { Client manager } \\
\text { (if necessary) }\end{array}$ & $\begin{array}{l}\text { Mentor }+ \text { Mentee }+ \\
\text { Family business owner } \\
\text { (or stakeholder) }\end{array}$ \\
\hline
\end{tabular}

Source: Wolverhampton (2009: 9-10)

\section{Mentoring in family businesses}

Six key characteristics can be identified (Salvato et al. 2012) which current family business leaders require of their next-generation leaders. These include integrity, commitment, ability to gain respect from nonfamily employees, decision-making abilities, experiences, interpersonal skills, intelligence, and self-confidence. Likewise, mentoring relationships are known to increase skills, knowledge, social networks, and selfconfidence (Dougherty-Dreher 2007; Eby et al. 2008). Because of similarities between the needs of next-generation leaders and the outcomes of mentoring, it can be assumed that family business leaders can benefit from mentoring relationships. There is evidence that family business leaders do indeed benefit from mentoring relationships (Boyd et al. 1999; Goldberg 1996; Tunkkari-Eskelinen 2005), and sources exist which can be used by family businesses to develop these relationships (Spector 2004).

The distinction between inter-organizational and intra-organizational mentoring can be an important factor for family businesses: 
- Intra-organizational mentoring could imply a father mentoring a daughter or a nonfamily CFO mentoring a next-generation family member.

- The inter-organizational mentoring might imply a CEO from one family business mentoring a next-generation leader in another family business.

According to the research that exists for family business on mentoring, inter-organizational mentoring seems to be more effective in producing leadership development (career focused) outcomes. Intra-organizational mentoring may be more effective in transferring organizational culture and values (psycho- social focused; Boyd et al. 1999; Distelberg-Schwarz 2013).

The phases of mentoring can be drawn up as follows (Clutterbuck 2005):

\section{Figure 3: Key characteristics of mentoring in family businesses}

\section{Phases of Mentoring:}

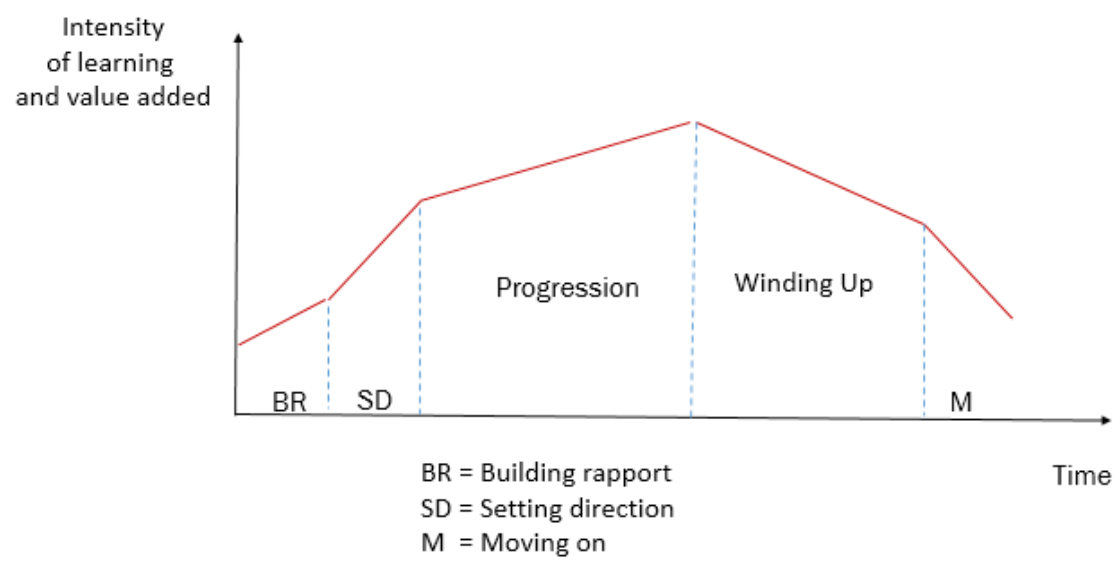

Source: Clutterbuck (2005: 2-3)

a) Goals: At an individual or dyadic level the effective mentoring relationships begin with a first stage of defining the relationship and identifying the mentee's goals. At individual level, these goals can be independent from the business, so the mentee can benefit from mentoring whether he or she stays in his or her current organization or moves to a new organization. In case of family businesses, the focus will be different as the mentee can stay in the same family business for their entire career (Salvato et al. 2012), so the mentee may not be able to differentiate his individual development from that of their family business. 
b) Resources: After identifying the goals, the next step to identify and also access resources to support the mentee's goals. For family businesses the same dyadic-level cost-benefit process can be assumed, but at the family business level, goals might require accessing other intangible resources located specifically in the family or ownership. An example of this type of resource might include family councils, governance boards, or even the intangible resource of 'familiness' (Habbershon-Williams 1999). In this case, family businesses engender a sense of togetherness and a shared culture that is valued by the business.

c) Experience: Within the studies of family business mentoring, it is clear that certain experiences work better with specific mentee's goals. In this case, external CEOs in other family businesses seem to align better with career-focused goals, whereas internal stakeholders seem to lend themselves to goals that are more psycho- social in nature (Boyd et al. 1999; Tunkkari-Eskelinen 2005). In a family business, based on the experiences of the mentor and taking into consideration of goals, it could be a good question that the mentor must be a CEO of a family business or CEO of a nonfamily business might be more effective, or a family stakeholder, like a chief emotional officer in the owning family system.

d) Commitment: Both the mentor and the mentee have to feel that they are committed to the relationship, and they are committed to the goals and direction of the relationship. This commitment will be the frame of their motivation and goals (AllenEby 2008). At the individual level, personality, emotional intelligence, and communication skills influence the level of commitment with the mentee. (Johnson-Ridley 2004; Turban-Dougherty 1994). The family business, as a system, would either allow or prevent an outside mentor from entering the system through a relationship with a mentee. If access to the family business ecosystem is necessary for the mentee's goals, it can be considered the commitment of the mentee's and mentor's family business.

e) Interpersonal skills: Extraversion, type A personality, ${ }^{3}$ internal locus of control, emotional intelligence, self-esteem (Johnson-Huwe 2003; Turban-Dougherty 1994), a desire to achieve affiliation with an organization (Fagenson 1992), communication skills (Johnson-Ridley 2004), and a willingness to learn (Allen-Eby 2004) have all been associated with positive outcomes in mentoring. In case of family business these interpersonal skills predominate as well, but the functionality, the fam-

3 The theory describes Type A individuals as outgoing, ambitious, rigidlyorganized, highly status-conscious, sensitive, impatient, anxious, proactive, and concerned withtime management. 
ily- business-ownership system dynamics are important as well, and the relations are free from destructive conflict or disunity.

Table 2: Individual versus family business mentoring processes

\begin{tabular}{|l|l|l|}
\hline \multicolumn{1}{|c|}{ Key process } & \multicolumn{1}{|c|}{ General mentoring } & \multicolumn{1}{c|}{$\begin{array}{c}\text { Extensions for family business } \\
\text { mentoring }\end{array}$} \\
\hline $\begin{array}{l}\text { Goal } \\
\text { focus }\end{array}$ & $\begin{array}{l}\text { Mentee's goals can be } \\
\text { conceptualized as goals rang- } \\
\text { ing from career to psychosocial } \\
\text { focused goals }\end{array}$ & $\begin{array}{l}\text { Mentee's bring interdependent } \\
\text { developmental goals into the mentor- } \\
\text { ing relationship creating } \\
\text { a multidimensional goals }\end{array}$ \\
\hline Experience & $\begin{array}{l}\text { Senior mentor with experience } \\
\text { in the developmental trajectory } \\
\text { of the mentee's }\end{array}$ & $\begin{array}{l}\text { Senior mentor with experience } \\
\text { in the developmental trajectory } \\
\text { of the mentee's family business }\end{array}$ \\
\hline Commitment & $\begin{array}{l}\text { Mentee's and mentor are interested } \\
\text { and motivated to support the } \\
\text { mentee's' developmental goals }\end{array}$ & $\begin{array}{l}\text { The mentee's and mentor's family } \\
\text { business must support the dyadic } \\
\text { relationship in its efforts to serve the } \\
\text { mentee's goals. These systems should } \\
\text { also be interested and motivated to } \\
\text { support the mentee's development }\end{array}$ \\
\hline Resources & $\begin{array}{l}\text { Access to mentor resources that } \\
\text { support the mentee's goals }\end{array}$ & $\begin{array}{l}\text { Access to the mentee's and mentor's } \\
\text { family business resources that } \\
\text { support the mentee's development }\end{array}$ \\
\hline $\begin{array}{l}\text { Interpersonal } \\
\text { skills }\end{array}$ & $\begin{array}{l}\text { Strong interpersonal skills; self- } \\
\text { esteem, emotional intelligence, } \\
\text { internal locus of control, a desire } \\
\text { to achieve, a willingness to learn } \\
\text { required of the mentee's and } \\
\text { mentor }\end{array}$ & $\begin{array}{l}\text { Functional, family- business- } \\
\text { ownership system dynamics, free } \\
\text { from destructive conflict or disunity }\end{array}$ \\
\hline
\end{tabular}

Source: Distelberg-Schwarz (2013: 6)

Utrilla and Grande (2013) analysed using structural equation methodology in a sample 630 Spanish companies, and the results show, that the mentoring influences employee performance and the firm's growth, and coaching and coach, who comes from outside the company but understands the values, culture, protocol, and behavioural norms of family businesses. also improves the performance of family businesses, being related to both employee performance and business growth. 


\section{Conclusion}

According to literature and surveys at least of the half of the family businesses will face with the process of succession in Hungary. It can be assessed as a positive factor that appr. the half of them have some kind of plan for succession, but the mainly these are informal plans. The planning of succession would have two relevant steps of selecting of the successor and setting criteria of possible candidates and the preparation for the transfer of management control as well as ownership shares from an older to a younger generation. The conscious and formal review and solution of four phases - as trigger phase, preparation phase, selection phase, and training phase - could support the successions very effectively. With these activities the main challenges and risks could be eliminated as well; creating a strategic thinking and planning and convert it to family governmental processes, be able to find a trusted advisor and the successor, treat the emotional issues and the disharmonies in the family.

In the planning of succession process, external advisors can provide support. In case of a concrete professional issue, problem where an exact solution is needed, the best to ask a consultant. If the family business cannot solve situations, run the company effectively from professional and personal aspects, and there is a need for improving of personal and executive skills, the recommended choice can be a coach. A business mentor is needed when the family business needs an experienced person for the longer term who understands the business and can give support with discussions, questioning without defining what the family business should do or saying the solutions.

As we presented in this paper, if the family businesses would conduct their business with more conscious on the future as well, it would focus their attention on succession planning as well, where they can ask supports from external experts and the existing methods could help them in the succession planning process. With these, the outdoer owner of the family business could assure the survival and the successful foreseeable future of the business.

\section{References}

Ahlers, O. - Hack, A. - Kellermanns, F. W. (2014): Stepping into the buyers shoes: Looking at the value of family firms through the eyes of private equity investors. Journal of Family Business Strategy, (5)4, 384-396. https://doi.org/10.1016/j.jfbs.2014.04.002. 
Allen, T. D. - Eby, L. T. (2004): Factors related to mentor reports of mentoring functions provided: Gender and relational characteristics. Sex Roles, (50)1-2, 129-139. https://doi.org/10.1023/b:sers.0000011078.48570.25.

Allen, T. D. - Eby, L. T. (2008): Mentor commitment in formal mentoring relationships. Journal of Vocational Behavior, 72, 309-316.

https://doi.org/10.1016/j.jvb.2007.10.016.

Bálint A. (2006): Merre tovább középvállalkozások? - Stratégiai lehetőségek a vállalkozásátadás folyamatában. (PhD-értekezés)

Boyd, J. - Upton, N. - Wircenski, M. (1999): Mentoring in family firms: A reflective analysis of senior executive's perspectives. Family Business Review, 12, 299-309. https://doi.org/10.1111/j.1741-6248.1999.00299.x.

Carlock, R. - Ward, J. (2001): Strategic planning for the family business: Parallel planning to unify the family and business. Palgrave Macmillan. https://doi.org/10.1057/9780230508750.

Chua, J. - Chrisman, J. J. - Sharma, P. (1999): Defining family business by behaviour. Entrepreneurship Theory and Practice, 23, 19-40. https://doi.org/10.4337/9781781002988.

Chua, J. - Chrisman, J. J. - Sharma, P. (2003): Succession and non-succession concerns of family firms and agency relationship with nonfamily managers. Family Business Review, 16, 89-108. https://doi.org/10.1111/j.1741-6248.2003.00089.x.

Clutterbuck, D. (2005): Establishing and maintaining mentoring relationships: An overview of mentor and mentee competencies.

https://doi.org/10.4102/sajhrm.v3i3.70.

Clutterbuck, D (2014): Everyone Needs a Mentor. (5th ed.) Kogan Page. https://doi.org/10.1016/b978-0-7506-3695-7.50002-0.

Clutterbuck, D. - Lane, C. (2004): The Situational Mentor. Routledge.

Csákné Filep J. (2012): Családi vállalkozások - Fókuszban az utódlás. Budapest: BCE.

Csizmadia, P. - Csillag, S. (2017): Business mentors' competences in intensive learning environments: Lessons from two case studies. In Eduardo, Tomé Sandra Costa - Proceedings of the 18th International Conference on Human Resource Development Research and Practice. Lisbon, Portugal: Universidade Europeia, 145-158. https://doi.org/10.1108/03090591111150077.

Daloz, L. (1986): Effective Teaching \& Mentoring. San Francisco: Jossey Bass.

Distelberg, B. J. - Schwarz, T. V. (2013): Mentoring across family-owned businesses. Family Business Review, (28)3, 193-210.

https://doi.org/10.1177/0894486513511327. 
Dougherty, T. W. - Dreher, G. F. (2007): Mentoring and career outcomes. In Ragins, B. R. - Kram, K. E. (eds.): The handbook of mentoring at work: Theory, research and practice, 51-94. Thousand Oaks, CA: Sage.

https://doi.org/10.4135/9781412976619.n1.

Eby, L. T. - Allen, T. D. - Evans, S. C. - Ng, T. - Dubois, D. L. (2008): Does mentoring matter? A multidisciplinary meta-analysis comparing mentored and non-mentored individuals. Journal of Vocational Behavior, 72, 254-267.

https://doi.org/10.1016/j.jvb.2007.04.005.

Fagenson, E.A. (1992): Mentoring - Who needs it? A comparison of protégés' and nonprotégés' needs for power, achievement, affiliation, and autonomy. Journal of Vocational Behavior, (41)1, 48-60.

https://doi.org/10.1016/0001-8791(92)90038-2.

Fenyvesi, É. - Kárpáti-Daróczi, J. - Vágány, J. B. (2015): Do we develop for the sake of development? Or what kind of training methods do leaders prefer today. Science Journal of Business and Management, (3)1-1, 59-65.

https://doi.org/10.14267/veztud.2016.12.07.

Gibson, S. K (2004): Mentoring in business and industry: the need for a phenomenological perspective. Mentoring \& Tutoring, (12)2, 259-275. https://doi.org/10.1080/1361126042000239974.

Goldberg, S. C. (1996): Research note: Effective successors in family-owned businesses: Significant elements. Family Business Review, 9, 185-197. https://doi.org/10.1111/j.1741-6248.1996.00185.x.

Gubik, S. A. - Farkas, Sz. (2017): National Report, GUESSS 2016. http://www.guesssurvey.org/resources/nat 2016/GUESSS Report 2016 Hungary.pdf. Habbershon, T. G. - Williams, M. (1999): A resource-based framework for assessing the strategic advantage for family firms. Family Business Review, 12, 1-25. https://doi.org/10.1111/j.1741-6248.1999.00001.x.

Hagerty, B. (1986): The second look at mentors. Nursing Outlook, (34)1, 16-24.

Heidrich, B. - Németh, K. - Chandler, N. (2016): Running in family - Paternalism and familiness in the development of family business. Vezetéstudomány, (47)11, 70-82. https://doi.org/10.14267/veztud.2016.11.08.

Johnson, W. B. - Huwe, J. M. (2003): Getting Mentored in Graduate School. Washington: American Psychological Association.

Johnson. W. B. - Ridley, C. R. (2004): The Elements of Mentoring. New York: Palgrave Macmillan. 
Kása R. - Radácsi L. - Csákné Filep J. (2017): Családi vállalkozások Magyarországon. Working Paper Series, Issue 4.

https://budapestlab.hu/wp-content/uploads/2018/04/WP-4-2017.pdf.

Konczosné Szombathelyi M. (2014): Családi vállalkozások generációváltásának kockázata. „A tudomány és a gyakorlat találkozása” Kautz Gyula Emlékkonferencia. http://kgk.sze.hu/images/dokumentumok/kautzkiadvany2014/KSZM.pdf.

Lansberg, I. - Astrachan, J. H. (1994): Influence of family relationships on succession planning and training: The importance of mediating factors. Family Business Review, 7, 39-59. https://doi.org/10.1111/j.1741-6248.1994.00039.x.

MacLennan, N. (1999): Coaching and Mentoring Hampshire. Gower. https://doi.org/10.4324/9781315260051.

Makó, Cs. - Csizmadia, P. - Heidrich, B. (2016): Succession in the family business: Need to transfer the socio-emotional wealth (SEW). Vezetéstudomány, (47)11, 16-29. https://doi.org/10.1177/2393957517749708.

Makó, Cs. - Csizmadia, P. - Heidrich, B. - Csákné Filep, J. (2017): Comparative report on family businesses' succession. Working Paper Series, Issue 2. https://budapestlab.hu/wp-content/uploads/2018/04/WP-2-2017.pdf.

Managers' and Mentors' Handbook on Mentoring, 2009. University of Wolverhampton.

Mandl, I. (2008): Overview of Family Business Relevant Issues. Austrian Insitute for SME Research. Contract No 30-CE-0164021/00-51. Final Report.

Martínez, J. I. - Stöhr, B. S. - Quiroga, B. F. (2007): Family ownership and firm performance: Evidence from public companies in Chile. Family Business Review, (20)2, 83-94. https://doi.org/10.1111/j.1741-6248.2007.00087.x.

Merriam, S. (1983): Mentors and proteges: A critical review of the literature. Adult Education Quarterly, (33)3, 161-173. https://doi.org/10.1177/074171368303300304.

Miller, D. - Steier, L. - Le Breton-Miller, I. (2003): Lost in time: Intergenerational succession, change and failure in family business. Journal of Business Venturing, (18)4, 513-531. https://doi.org/10.1016/s0883-9026(03)00058-2.

Mussolino, D. - Calabro, A. (2014): Paternalistic leadership in family firms: Types and implications for intergenerational succession? Journal of Family Business Strategy, (5)2, 197-210. https://doi.org/10.1016/j.jfbs.2013.09.003.

Németh K. (2018): Családi vállalkozások teljesitményének endogén tényezöi. Thesis, SZE, Györ. http://phd.szerep.sze.hu/?docId=52070.

Németh K. - Németh Sz. (2017): A vezetői számviteli és controlling módszerek alkalmazása és szerepe a családi vállalkozások működtetésében, utódlási folyamatainak 
sikeres menedzselésében - egy empirikus felmérés tapasztalatai, Controller Info, különszám, 213-229.

Nicholson, H. - Shepherd, D. - Woods, C. (2010): Advising New Zealand's family businesses: Current issues and opportunities. University of Auckland Business Review, (12) $1,1-7$.

O'Brien, V. (2003): It's all in who you know. BC Business, (31)12, 19.

Palócz É. - Vakhal P. (2018): Mi lett velük? Egy kiterjesztett esettanulmány tanulságai a középvállalati réteg sorsának alakulásáról 2000-2016 között. Társadalmi Riport 2018/Gazdaság, 1-14.

Parsloe, E. - Wray M. (2004): Coaching and Mentoring - Practical Methods for Improving Learning. London: Kogan Page.

Roberts, A. (2000): Mentoring Revisited: A phenomenological reading of the literature, Mentoring and Tutoring, (8)2, 145-170.

Rothwell, W. J. (2010): Effective succession planning - Ensuring Leadership Continuity and Building Talent from Within. (4rd ed.) AMACOM.

Salvato, C. - Corbetta, G. (2013): Transitional leadership of advisors as a facilitator of successor's leadership construction. Family Business Review, 26, 235-255. https://doi.org/10.1177/0894486513490796.

Salvato, C. - Minichilli, A. - Piccarreta, R. (2012): Faster route to the CEO suite: Nepotism or managerial proficiency. Family Business Review, 25, 206-224. https://doi.org/10.1177/0894486511427559.

Sági, J. (2017): Credit guarantees in sme lending, role, interpretation and valuation in financial and accounting terms. Economics Management Innovation, (9)3, 62-70.

Sági, J. - Korom, E. (2005): Measures on competitiveness in agriculture. Journal of Central European Agriculture, (6)3, 375-380.

Sharma, P. (2004): An overview of the field of family business studies: current status and directions for the future. Family Business Review, (17)1, 1-36.

https://doi.org/10.4337/9781847204394.00010.

Sharma, P. - Chrisman, J. J. - Chua, J. H. (2003): Succession planning as planned behavior: Some empirical results. Family Business Review, 16, 1-15.

https://doi.org/10.1111/j.1741-6248.2003.00001.x.

Shea, G. F, (1992): Mentoring; a Guide to the Basics. London: Kogan Page.

Spector, B. (2004): The Family Business Mentoring Handbook. Philadelphia, PA: Family Business Publishing. https://doi.org/10.1111/j.1741-6248.2005.039 1.x. 
Tunkkari-Eskelinen, M. (2005): Mentored to feel free: Exploring family business next generation members experiences of non-family mentoring (Unpublished doctoral dissertation). Jyväskylä University, Jyväskylä, Finland.

Turban, D. B. - Dougherty, T. W. (1994): Role of protégé personality in receipt of mentoring and career success. Academy of Management Journal, (37)3, 688-702. https://doi.org/10.5465/256706.

Turner, A. N. (1982): Consulting is more than giving advice. Harvard Business Review, (60)5, 120-129. https://hbr.org/1982/09/consulting-is-more-than-giving-advice.

Tyler, K. (2004): Is it mentoring or coaching. HR Magazine, (49)3, 89.

Utrilla, N. C. - Grande, T. F. A. (2013): The importance of mentoring and coaching for family business. Journal of Management and Organization, 19, 386-404. https://doi.org/10.1017/jmo.2013.28.

Wanberg, C. R. - Welsh, E. T. - Hezlett, S. A. (2003): Mentoring research: A review and dynamic process model. In Martocchio, J. - Ferris, J. (eds.): Research in Personnel \& Human Resource Management, 22, 39-124. Oxford Elsevier Science Limited. https://doi.org/10.1016/s0742-7301(03)22002-8.

Wieszt A. - Drótos Gy. (2018): Családi vállalkozások Magyarországon. Társadalmi Riport 2018/Gazdaság, 233-247.

Whitely, W. - Dougherty, T. W. - Dreher, G. F. (1992): Correlates of career-orientated mentoring for early career managers and professionals. Journal of Organizational Behavior, (13)2, 141-154. https://doi.org/10.1002/job.4030130204.

Zentis, N. (posted) (2016): The 15 types of coaching. Institute of Organisational Development. nancy.zentis@instituteod.com.

Zey, M. G. (1984): The Mentor Connection. Homewood, USA: Jones-Irwin. https://doi.org/10.2307/2070197.

This paper was written as part of the project 2016-1-HU01-KA203-022930) ERASMUS+ Strategic Partnership for Higher Education with support of the European Commission. This publication reflects only the views held by the author, and the Commission cannot be held responsible for any use which may be made of the information contained therein. 